\title{
The Frescoes in the Crypt of Saint Adam
}

\section{Nineteenth-Century Interpretations of Canon Angelo Maria Rocchia and Differences with Current Studies}

\author{
Nadia Raimo | ORCID: 0000-0002-0295-6351 \\ Doctoral student, Digital Humanities Department, University of Genoa, \\ Italy \\ nadia.raimo@gmail.com
}

\begin{abstract}
This essay explores bibliographic and historiographical studies on the frescoed vaults in the crypt of Saint Adam, located in the church of Santa Maria Maggiore in Guglionesi (Campobasso province, Molise, Italy). The frescoes have never been the subject of a detailed study; in fact, they have received only sporadic mention in some volumes of Molise art and history. The most ancient bibliographic information that can be recovered is reported in the nineteenth-century La Cronistoria di Guglionesi by Canon Angelo Maria Rocchia (Guglionesi, 1830-1907) and the three glorious translations by the medieval Benedictine monk Saint Adamo Abate (990-1070). The canon mentioned the historical events that led to the establishment of the crypt and the changes in its pictorial decoration. This essay begins with Canon Rocchia's hypotheses and moves on to further investigate the crypt and the history of the frescoes, bringing to light similarities and differences in the interpretation of the pictorial decorations.
\end{abstract}

\section{Keywords}

crypt - vault decoration - church historiography - Adamo Abate - Molise art

This essay concerns the frescoes that decorate the vaults of the crypt of Saint Adam, located in the church of Santa Maria Maggiore in Guglionesi (Molise, Italy). The frescoes have never been the subject of a detailed and in-depth study, being only sporadically mentioned in some volumes of art and history of Molise. 
The most ancient bibliographic information regarding the vault is contained in the nineteenth-century text by Canon Angelo Maria Rocchia (Guglionesi, 1830-1907), La Cronistoria di Guglionesi e delle tre gloriose traslazioni di $S$. Adamo Abate suo protettore. That volume mentions the Romanesque origin of the church (eleventh-twelfth/fourteenth century) and its construction phases, even if insufficient information is reported about the construction of the crypt and its use over the centuries. The canon reported more detailed information on what were the last eighteenth-century restorations in the church itself; in 1746 , the building was largely rebuilt before being blessed in $1796 .{ }^{1}$ The previous appearance was completely modified, with the exception of the apsidal basins of the three naves of the church, the presbytery, and the crypt, all of which still today retain the medieval layout.

The crypt, dedicated to Saint Adam, measures $6.40 \mathrm{~m}$ wide and 21.6o $\mathrm{m}$ in length ${ }^{2}$ and is divided by two aisles separated by round arches that are set on capitals and columns, probably used in a previous construction. In the rear part of the aisles there is the Chapter Room where the central vault is set on four arch-stones.

Regarding the origins of Saint Adam, Canon Rocchia did not report certain information. The hagiographic stories to which he referred tell of the saint's arrival in the town of Guglionesi in 1020. ${ }^{3}$ The canon specified that in the town, the relics of Saint Adam were moved three times; in particular, he reported that the last translation took place following the Turkish invasion, in the $156 \mathrm{os}$, whose destructive fury involved the church of Santa Maria Maggiore as the victim of events. Consequently, the body of Saint Adam was removed from the crypt and, according to the canon, the relics were deposited in the Chapter Archives, a place that later was set on fire by an anonymous feudal lord who wanted to hide any trace of some compromising documents. ${ }^{4}$ According to the hypotheses of Canon Rocchia, the relics were irretrievably lost after this last move.

In the sixteenth century, perhaps following the second translation of the relics of Saint Adam from Campobasso to Guglionesi, the crypt was initially decorated with monochrome motifs, then was redecorated, around 1587, by frescoes that are still partially visible on the vaults. ${ }^{5}$ Canon Rocchia reports in

1 Rocchia, Cronistoria di Guglionesi, 40.

2 Cioffari and Sorella, Sant'Adamo di Guglionesi, 303.

3 Rocchia, Cronistoria di Guglionesi, $5^{8-61 .}$

4 Rocchia, Cronistoria di Guglionesi, 135-136.

5 Rocchia, Cronistoria di Guglionesi, 135-136. 
his testimony that 'among the (commissioned) decorations, around 1587 (the citizens) ordered some paintings, which portrayed the life of Saint Adam and the facts of Sacred History'. 6 In addition, he also hypothesized as to the possible origin of the artist who executed the frescoes, defined by him as 'a famous Roman painter who took refuge [...] in Guglionesi'?

Since the canon's death, the study of the crypt of Saint Adam languished, with only sporadic hints in some volumes of Molise art. ${ }^{8}$ Interest reignited with the 1978 restorations, promoted by the Archaeological Superintendence to recover the environmental, architectural, artistic, and historical heritage of Molise, and with the 1989 restoration files compiled by the researcher Silvia Cerio, ${ }^{9}$ from which emerged intriguing questions about possible Roman reference models. Cerio identified the subjects that decorate the vaults, clarifying that they are representations of the stories of Genesis, in particular the stories of Noah, thus contradicting Rocchia's opinion, which affirmed that the frescoes represented religious episodes mainly linked to the life of Saint Adam. ${ }^{10}$

Considering these premises, current research brings attention to the presence of further biblical scenes that would refute, at least partially, the hypotheses of both Silvia Cerio and Angelo Maria Rocchia. Recent analysis of the iconographic cycle has hypothesized a reading of the scenes following the chronological order of the events narrated, starting from the main vault of the Chapter Room and continuing along the two side aisles. The main vault (Fig. 1) is divided into a central panel and four trapezoidal partitions, profiled by denticles and frames with vegetal and ribbon motifs. The central panel presents the figure of God the Father in the act of Creation. The episode, in turn, is delimited by four ovals with scenes that represent the Creation of Eve (Gen. 2:18-25), the Temptation and Fall of Adam and Eve (Gen. 3:1-6), the Expulsion of Adam and Eve from the Garden of Eden (Gen. 3:1-19), and the Offerings of Cain and Abel (Gen. 4-5).

The narration continues in the vaults of the left aisle, where the frescoes are outlined by a double frame: the outer one formed by festoons of leaves and flowers, and the inner one simulating the golden stucco (Fig. 2). Both show scenes related to the life of Noah: Noah's Ark and the collection of animals (Gen. 6:9-22); the Great Flood (Gen. 7:4-10); and the Drunkenness of Noah

\footnotetext{
6 Rocchia, Cronistoria di Guglionesi, 141.

7 Rocchia, Cronistoria di Guglionesi, 141.

8 Mortari, Molise, appunti per una storia dell'arte, 16.

9 Cerio, Scheda OA.

10 Rocchia, Cronistoria di Guglionesi, 141.
} 
(Gen. 9:20-27). The last fresco, still present, shows images of the construction of the Tower of Babel (Gen 11:1-9), which confirms the presence of further episodes from Genesis. Different reasoning applies to the aisle on the right, where only a single fragment of the fresco can be seen. In the partial image, nonetheless, it is possible to glimpse in the foreground an elderly man leaning on a stick; behind him in the background, what would seem to be a chariot; and in the distance a Roman aqueduct. The presence of these elements suggests that the representation alludes to the Exodus from Egypt and to the episode of Moses separating the waters, allowing the Jewish people to cross the Red Sea (Ex. 14:15-22).

Due to the poor state of conservation of the frescoes, it should be noted that it was not possible to define a more specific narrative scheme.

The decorations show evident stylistic and compositional connections with the Roman Mannerist environment. The materiality of the characters recalls the robustness of Michelangelo's bodies, such as the mighty musculature of the Saved and the Damned that surrounds the figure of the Savior in the Last Judgment (1508-1511) of the Sistine Chapel and the vigor of the limbs of the characters of the Genesis stories represented on the time of the same place."

The comparison with the Roman Mannerist environment does not help identify the origin of the anonymous painter, but it could provide information on his period of artistic training and on the acquisition of some pictorial models. It is true that Roman art of the sixteenth century is not the only influence on the style of the Molise frescoes, as becomes clear from comparison with other works present in the Molise area. The most significant example is located in the castle of the di Capua family, which is in Gambatesa.

A comparison between Guglionesi and Gambatesa brings out similarities that are visible not only in the frames of the ornamental plants, present both in the chapel of Saint Adam and in the rooms of the castle, but also in the figurative rendering of the subjects and in the construction of the landscape scenes. The stylistic affinities clearly suggest that the possible executor of the Guglionesi frescoes may have been the artist who worked in Gambatesa, Donato de Cumbertino. However, this thesis is contradicted by chronological inconsistencies, since Donato, of Apulian origin, would have had a first phase of artistic training in his hometown, probably Nardò (Lecce province), and subsequently, in the first half of the sixteenth century, would have moved to Rome, where he would have acquired the Roman Mannerist models that he later adopted in the castle rooms. The Apulian artist was already quite old dur-

11 Pfeiffer, La Sistina svelata, 186. 
ing the work in the castle of Gambatesa, whose completion is dated to $155^{\circ}$, making his collaboration in the crypt very unlikely, as work there was not complete until 1587 .

The most plausible hypothesis as to the identity of the author, or the authors, of the frescoes that adorn the vaults of the crypt is that Donato had at his service a workshop, or in any case collaborators, who had helped him complete the work in the castle of the di Capua family. It is quite probable, therefore, that his workshop, or some pupil very close to him, was called to create the frescoes in the crypt and made use of the preparatory cartoons made by Donato.

\section{Bibliography}

Cerio, S., Scheda OA, Archivio di Stato di Campobasso, NCTR, No. ooo17341, Campobasso, 1978.

Cioffari, G., and L. Sorella, Sant'Adamo di Guglionesi. Abate nel monastero benedettino delle isole Tremiti, Campobasso, Palladino, 2005.

Mortari, L., Molise, appunti per una storia dell'arte, Rome, De Luca, 1984.

Pfeiffer, H.W, La Sistina svelata: Iconografia di un capolavoro, Milan, Jaca Book, 2010.

Rocchia, A.M., Cronistoria di Guglionesi e delle tre gloriose traslazioni di S. Adamo abate suo protettore, Vasto, Arte della stampa Cannarsa, 1991. 


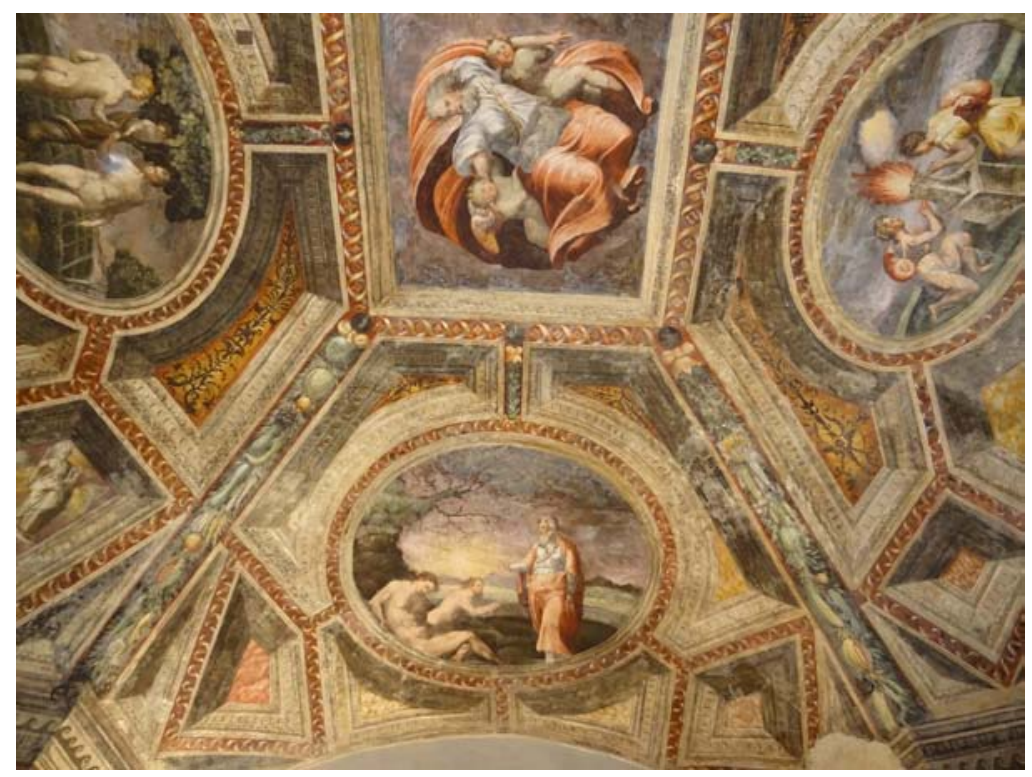

FIGURE 1 Unknown artist, The main vault, c. 1587, Church of Santa Maria Maggiore, Guglionesi

PHOTO CREDIT: CNADIA RAIMO, AUTHOR

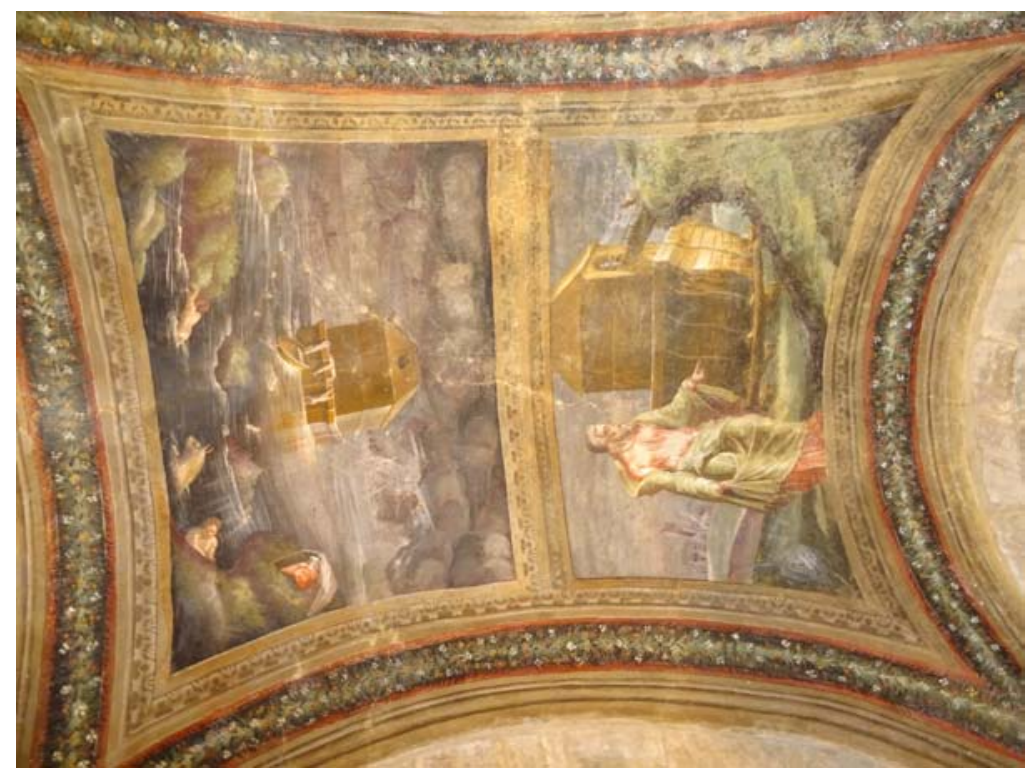

FIgURE 2 Unknown artist, Noah's Ark and The Great Flood, c. 1587, Church of Santa Maria Maggiore, Guglionesi PHOTO CREDIT: CNADIA RAIMO, AUTHOR 